\title{
Radosław Kossakowski*
}

\author{
Uniwersytet Gdański
}

\section{PERFORMANS NA TRYBUNACH. O KULTUROWO-DRAMATURGICZNYM ASPEKCIE KIBICOWANIA}

\begin{abstract}
Głównym celem poniższego tekstu jest pokazanie, że w pewnym wymiarze działalność i aktywność kibiców noszą znamiona performansu. Uwagę skupiono na „hardcorowych” kibicach piłkarskich (odłam „ultras”, odpowiedzialni za meczowe choreografie) w Polsce. Performanse kibicowskie nie są tylko przedstawieniami estetycznymi, ale stanowią także zróżnicowane pod względem formy reprezentacje treści kulturowych. Prezentowanie umiejętności czysto technicznych (przygotowanie opraw meczowych itp.) przenika się z kulturowym „tłem”. W przypadku kibiców konstytuują je przede wszystkim opozycje, antypatie, chronologie i analogie. Bardzo ważną rolę w przedstawieniach kibicowskich odgrywa szeroko rozumiana tradycja (historia klubu, ale i historia regionu czy Polski). Analiza performansów umieszczona jest w szerszym kontekście przemian współczesnej piłki nożnej, jej komercjalizacji. „Tradycyjni” fani ustępują nowej grupie kibiców-konsumentów, a dla tych pierwszych kreowanie publicznych pokazów staje się jednym z ostatnich bastionów prezentowania treści własnej kultury i grupowej tożsamości.
\end{abstract}

Słowa kluczowe: kultura kibicowania, teoria performansu, współczesna piłka nożna, choreografie, rama interpretacji

\section{WSTĘP I ZAŁOŻENIA TEORETYCZNE}

Tekst jest próbą analizy tego, co przedstawiają kibice piłkarscy za pomocą śpiewów, transparentów, flag, i umieszczenia owego „przedstawienia” w ramach teorii performansu. Głównym celem jest pokazanie, że w pewnym wymiarze, działalność i aktywności kibiców noszą znamiona performansuํ. Należy podkreślić, że pojęcie performansu nie ma jednej

* Adres do korespondencji: Radosław Kossakowski, Uniwersytet Gdański, ul. Bażyńskiego 4, 80-952 Gdańsk.

1 Fenomen piłki nożnej był już analizowany przez antropologów, kulturoznawców, a nawet teatrologów. Dariusz Kosiński wspomina: „Mecz piłkarski jest widowiskiem, w którym odnaleźć można aspekty teatralne. Więcej nawet: twierdzę, że mecz piłkarski nie osiąga swojej pełni, jeśli nie staje się widowiskiem” (2012: 94). Fani futbolu są postrzegani jako ,aktorzy współczesnych widowisk sportowych” (zob. Sahaj 2012). O działalności kibiców piłkarskich jako formy performansu wspomina Dagmara Łuba (2012), jednak w swej narracji nie korzysta z żadnej właściwie teorii performansu, w skromny także sposób odnosi się do wątków związanych z kulturą kibicowską, która wydaje się w tym przypadku kluczowa. Innymi słowy, bez odniesień do kulturowych, ale i aksjologicznych treści świata kibiców każda analiza ich „występów” staje się powierzchowna. 
definicji i jest stosowane w wielu aspektach: „To zwyczajne angielskie słowo, oznaczające tak wiele - wykonanie czegoś, przeprowadzenie jakiejś operacji, dokonanie czegoś, jakieś osiągnięcie, wydajność, pełnienie jakiejś roli, odprawienie obrzędu, odegranie czegoś, występ, numer cyrkowy, show, koncert, interpretację utworu muzycznego, inscenizację dramatu, kreację roli, przedstawienie teatralne, widowisko - będzie robić $\mathrm{w}$ humanistyce zawrotną karierę" (Kolankiewicz 2005: 17). O wieloznaczności terminu wspomina również Richard Schechner: „W świecie biznesu, w sporcie czy w seksie angielski czasownik perform znaczy, że sprostało się wymaganiom, osiągnęło sukces, spełnienie. W świecie sztuk perform znaczy wystawić, zagrać, zatańczyć, wystąpić ze spektaklem czy koncertem. W życiu codziennym perform to popisać się, pójść na całego, uwydatnić własne czynności na użytek tych, którzy je oglądają. W XXI wieku nasze życie jest naznaczone performansami bardziej niż kiedykolwiek" (2006: 43).

R. Schechner wymienia osiem rodzajów i siedem funkcji performansu. Te pierwsze wyodrębnia w życiu codziennym, w sztuce, w sporcie i innych rozrywkach popularnych, w biznesie, technologii, w seksie, w świętych i świeckich rytuałach, w zabawie. Funkcje oznaczają, że performans ma: zabawiać, tworzyć coś pięknego, ustanawiać lub zmieniać tożsamość, budować lub podtrzymywać wspólnotę, uzdrawiać, nauczać, przekonywać, wmawiać, obcować z tym, co święte lub demoniczne (tamże: 46, 52). Natomiast Jeffrey C. Alexander (2010b) wymienia kilka elementów składających się na performans: przedstawienia zbiorowe (symbole tła i scenariusze), środki produkcji symbolicznej, aktorzy, publiczność, mise-en-scéne, władza społeczna. Wszystkie te elementy w efektywnie odegranym spektaklu muszą się „zgrać”, muszą być złączone. Od tego zależy uznanie performansu za autentyczny.

Próbę usystematyzowania dokonań teoretycznych dotyczących ,performansu” podjął Jacek Wachowski (2011). Oprócz dokonania wielowątkowej analizy zjawiska, jego historycznych źródeł i interdyscyplinarnej debaty wokół jego znaczenia, formułuje on kilka kluczowych cech dystynktywnych, którymi dane działanie musi się charakteryzować, by można było je nazwać performansem. Przede wszystkim, performanse charakteryzują się pragmatycznością - służą jakimś celom, wypełniając pewne funkcje. Mogą to być funkcje materialne (np. wystawianie przedstawień komercyjnych przez teatr, by zdobyć środki na bieżącą działalność), a także emocjonalne, duchowe, estetyczne. Cele mogą dotyczyć zarówno performerów, jak i widzów, obustronnie mogą także być zrozumiałe/niezrozumiałe, przydatne bądź nie. Performanse wyróżniają się specyficzną strukturą. Muszą być wyeksponowane, bowiem obecność publiczności jest kluczowa (udział publiczności może być bezpośredni lub zapośredniczony np. przez media). Mają delimitowany charakter (mają mniej lub bardziej wyraźny początek i koniec), są iterowalne (nigdy nie są takie same, nawet jeżeli powtarza się dane motywy w tym samym miejscu i przestrzeni). Performanse mają także zdolność zaburzania równowagi w definiowaniu danej sytuacji.

Ta różnorodność znaczeń i sensów pozwala lepiej zrozumieć istnienie wielu możliwości wykorzystania tego pojęcia. Jak pisze Tomasz Kubikowski: „Jego inspirujący potencjał błyszczy jednak w całej pełni” (2007: 14-15). Bogactwo znaczeniowe ma także swoją wadę.

Choreografie na stadionach nie są „pustą formą”, a wynika to m.in. z tego, że fani „,chcą tylko, poprzez kibicowanie, uczestniczyć w przestrzeni aksjologicznej nakreślonej przez tradycję klubu" (Pasek 2012: 107). 
Trzeba bowiem dokonać pewnej selekcji, a to, jak nie trudno odszyfrować, nakłada na badacza obowiązek arbitralnego skonstruowania narzędzia analizy. Badacz przez arbitralny wybór ze sfery wartości i pojęć tworzy swój własny performans - „pokaz umiejętności” (tu: analitycznych) bazujących na pewnej treści kulturowej. Przez taki arbitralny zabieg nadaje nowy sens znaczeniom ukutym w przeszłości. Przez nowe odczytanie istniejących pojęć umożliwia dostrzeżenie tego, że kultura: ,żyje, jest wrażliwa na kontekst i cały czas wyłania się na nowo" (Bruner 2011: 20). Dotyczy to rzecz jasna zabiegów analitycznych dokonywanych przez badacza, a także powtarzanych (choć nigdy nie takich samych) „zabiegów” dokonywanych przez kibiców.

W związku z tym wybrane przeze mnie znaczenia pojęcia „,performansu” wynikają z ujmowania kultury jako takiej sfery, która objawia się w działaniu czy „,przedstawieniu”. Na użytek niniejszej analizy dokonano połączenia pojęć performansu z dwóch zakresów, o których wspomina Marvin Carlson (2007: 28). Jeden związany jest z pokazem umiejętności, drugi również jest związany z pokazem, lecz nie tyle konkretnych umiejętności, ile uznanego i kulturowo skodyfikowanego wzorca zachowań. Pokaz umiejętności jest swoistym „przejawem życia” nie tylko poszczególnych jednostek uczestniczących w pokazie, ale także kultury, której wartości te jednostki chcą przekazać: „Performans kulturowy jest procesem społecznym, poprzez który aktorzy, indywidualnie bądź zbiorowo, prezentują innym znaczenie swej sytuacji społecznej” (Alexander 2010b: 370). Według Johna J. MacAloona natomiast „performanse kulturowe”2 są „czymś więcej niż rozrywką, czymś więcej niż dydaktycznymi czy przekonującymi zwrotami, czymś więcej niż katartyczne pobłażanie. Są okazjami, w których jako kultura czy społeczeństwo, odzwierciedlamy i definiujemy siebie, uwznioślamy nasze kolektywne mity i historię, proponujemy alternatywy, oraz zarazem zmieniamy się pod pewnymi względami, pozostając niezmiennymi pod innymi” (1984: 1). W przypadku performansów kibicowskich odzwierciedleniu ulega kultura tej grupy, jej kolektywne narracje i klasy znaczeń. Performanse kibiców są zatem dramaturgiczno-kulturowe, ponieważ treści kultury są „wystawiane” w specyficznym „przedstawieniu”, ale rozumianym w znaczeniu Ervinga Goffmana (1981).

Ważne jest, by na „pokaz umiejętności” kibiców nie patrzeć tylko z perspektywy „technicznej" - analizując detale przedstawienia, otoczenie pokazu, a zatem tylko strukturę, formę

\footnotetext{
2 W tekście stosuję zamiennie określenia „,performans” i „performans kulturowy”. Angielskie zwroty performance oraz cultural performance tłumaczone są niekiedy jako „widowisko” i „,widowisko kulturowe”. Wybór słowa „performans”, a nie „widowisko” wiąże się z tym, że performans wydaje się obejmować szersze spektrum zjawisk (zob. Duda 2011: 18). To kwestie złożonych relacji działań i procesów, przemiany świata, kultury, która jest przedstawiana. Performanse wcale nie muszą być widowiskowe, choć często korzystają z estetycznych form, by unaocznić różnicę i podjąć próbę przekonywania do siebie osób z zewnątrz. Inną różnicą jest to, że widowiska bywają naturalne (np. tęcza), performanse są zawsze dziełem człowieka. Pojęcie performansu wydaje się bardziej uniwersalne niż słowo „rytuał”. Ten ostatni, jak pokazuje Isaac Reed (2006), uniemożliwia często zaprezentowanie antagonizmów i opozycji, pełniąc często funkcje afirmatywne dla jakiejś wspólnoty. W przypadku społeczności kibicowskiej sfery rytuału i performatywności mogą jednak koegzystować. W pierwszym przypadku można mówić o funkcjonowaniu ,rytuałów interakcyjnych” o silnym natężeniu energii emocjonalnej. Performans może towarzyszyć owym rytualnym doświadczeniom, ale tylko do pewnego stopnia. Rytuały we wspólnocie mogą być pozbawione motywacji zainteresowania publiczności. Pojęcie rytuału bywa stosowane w analizach świata kibiców. Zbigniew Pasek wspomina, że uczestnictwo w życiu kibiców (badał fanów Cracovii Kraków) spełnia kilka funkcji rytuału religijnego (2012).
} 
takiego zachowania czy wartości estetyczne. Mówiąc językiem Ervinga Goffmana (2010), to nie wystarczy, by opisać samą „ramę” zachowania kibiców, która stanowi specyficzny „schemat interpretacyjny”. W perspektywie tego socjologa performans to działanie mające na celu stworzenie ram umiejscawiających określoną sekwencję działań przed osobami, które występują w roli widzów. Ramy, mawiał E. Goffman, służą do wyróżniania „urywków doświadczenia", są kluczowe w podkreślaniu istotności tych doświadczeń i znaczeń, które w innym przypadku pozostawałyby ważnym, lecz nie do końca uświadamianym „tłem”. „Ramy”, to mówiąc bardziej dosłownie, organizacyjna odpowiedź na pytanie „co się tutaj dzieje” (Czyżewski 2010). Niezmiernie ważny jest fakt, iż owe „schematy interpretacyjne” nie są zazwyczaj wytwarzane przez jednostkę, ale wynikają z zasobów kulturowo uformowanych definicji sytuacji (tamże: XXIV). Niezbędne staje się w tym kontekście dodanie do analizy warstwy „kulturowej”, która stanowi fundament pokazu kibiców i bez której „performans ramowy" (tamże: XV) niewiele by znaczył.

Jak zauważył Victor W. Turner: „Kultury najpełniej wyrażają się i nabierają samoświadomości poprzez swoje rytuały i performanse. (...) Performans jest dialektyką «przepływu», to znaczy spontanicznego ruchu, w którym działanie i świadomość stanowią jedno, oraz «refleksyjności», w której zasadnicze sensy, wartości i cele ukazują się «w działaniu», kształtując i wyjaśniając zachowanie. Performans jest świadectwem naszego wspólnego człowieczeństwa, ale wyraża też wyjątkowość poszczególnych kultur. Wnikając w swoje performanse i ucząc się ich gramatyki i słownictwa, lepiej się wzajemnie poznamy" (za: Schechner 2006: 33). Przez performans kibice ukazują swoje przeżycia i doświadczenia, mające źródła w pewnym kontekście społecznym i kulturowym. Społecznym, bo kibice tworzą wspólnotę, w której rodzą się więzi, zależności, struktura i hierarchia; kulturowym, gdyż to wszystko zasadza się na wartościach, normach, znaczeniach i symbolach. Analizując kibicowskie „performanse” warto zatem przyjrzeć się treściom kulturowo-społecznym, które stoją u ich źródeł. Forma „pokazu umiejętności” ma swoje korzenie w specyficznej kulturze kibicowania i nie powinna być analizowana w oderwaniu od tego swoistego „tła zbiorowych przedstawień” (Alexander 2010b: 371).

Kibice piłkarscy mają swój własny kulturowy świat funkcjonujący w szerszej społecznej całości. Mają swoje specyficzne normy, system wartości, a także zbiór wytworów technicznych, przedmiotowych, które stanowią reprezentację tych norm w świecie materialnym. Jak przekonuje Jakub Mosz: „Wizualno-wokalna oprawa stadionowa jest formą dynamiczną, ulotną, przypisaną do czasu i miejsca jej prezentacji. Wprowadza element zaskoczenia poprzez sposób jej prezentowania. Przekazuje treści składające się na narracje tożsamościowe tworzących ją kibiców ultras, nałożone na kontekst sportowej rywalizacji, odzwierciedlające sposób jej postrzegania przez kibiców klubowych, treści podkreślające sportowy etos klubu czy przypominające o ważnych dla lokalnych społeczności wydarzeniach" (2009: 153). Owa tożsamość kibiców wynika z kultury kibicowskiej, kultury w której zawierają się różnorodne treści: polityczne, społeczne, historyczne.

Zasadność wykorzystania teorii performansu wiąże się z kilkoma kwestiami. Po pierwsze, biorąc pod uwagę elementarną strukturę życia ludzi, można - za Jeffreyem C. Alexandrem (2010a) - uznać, że ludzie, bez względu na typ społeczeństwa, do jakiego należą, poszukują 
głębszych odniesień egzystencjalnych, poszukują, mówiąc wprost, „zbawienia”’3. Owe poszukiwania wyrażają się w kulturowych praktykach, w których kardynalne znaczenia mają swój wyraz - „fakty nie mówią za siebie, muszą więc być kulturowo przedstawione” (Bartmański 2010: XXII). Aktorzy sięgają po kody dostarczające analogii i antypatii (opozycji pomagających kształtować tożsamość „My”), a także narracje wpisujące się w kulturową chronologię (Alexander 2010b: 371). Wszystko to, by ukazać znaczenie wiążące dramaturgiczne przedstawienie z „tłem”. Przykład wyrażanej ,,antypatii” przywołuje Jakub Mosz, gdy wspomina o tym, że ,z performance oprawy ultras może łączyć stosowany przy prezentacji oprawy element zaskoczenia, sprzeciw przeciwko oficjalnym elementom oprawy stadionowej koncentrującym się na reklamie i wyrazisty element bezpośredniego kontaktu z publicznością" (2009: 156).

Aktywności kibiców noszą znamiona performansu również z tego powodu, że da się w nich wyodrębnić zjawisko „zachowanego zachowania”, obejmujące „działania fizyczne, słowne lub wirtualne, które odbywa się nie po raz pierwszy; przygotowane i wypróbowane. Można nie mieć świadomości, że własne zachowanie w danej chwili jest odtworzeniem zachowanego zachowania" (Schechner 2006: 44). Oczywiste staje się stwierdzenie, że kolejny „pokaz umiejętności” jest inny od poprzedniego. Potwierdza to również R. Schechner: „Performanse tworzy się z kawałków «zachowanego zachowania», ale każdy performans jest różny od innych. Po pierwsze bowiem, ustalone skrawki zachowania można zestawiać ze sobą w nieskończonej liczbie kombinacji. Po drugie, żadne zdarzenie nie stanowi dokładnie kopii innego. Nie tylko samo zachowanie - niuanse nastroju, ton głosu, język ciała i tym podobne - lecz także jego szczególne okoliczności i kontekst; to wszystko czyni każdy kolejny przypadek niepowtarzalnym" (tamże: 45). Performanse są zatem iterowalne (Wachowski 2011: 287).

O tym, że z ,zachowanym zachowaniem” mamy do czynienia w działalności kibiców piłkarskich przekonuje np. opis derbów rozgrywanych w IV lidze podkarpackiej pomiędzy „Igloopolem” Dębica i „Wisłoką” Dębica (relację przedstawia czasopismo „To My Kibice” w numerze 11/2011; artykuł nie ma tytułu i autora; składa się na niego relacja anonimowych kibiców). Kibic „Igloopolu”: „Miesiąc przed derbami zaczęły się prace przygotowawcze, w których brali udział w szczególności kibice, powiększyliśmy klatkę do 738 miejsc oraz przez wymagania ustawodawcy ponumerowaliśmy miejsca na całym stadionie" (s. 32). Podobną ,atmosferę” wyraża w tym samy numerze pisma kibic „Radomiaka” Radom (rywalem „Radomiaka” jest „Broń” Radom): „To nie mecz, to derby... wiadomo przygotowania, oprawa, zbiórki osiedlowe. Dzień przed derbami zbieramy się w około 80 osób na treningu piłkarzy, rozwieszamy transparent (...)" (s. 8). W jednym przypadku można nawet mówić o „performansie” jeszcze przed meczem piłkarskim. Relacja kibica „Widzewa” Łódź z przygotowań do derbów z „ŁKS” Łódź w tym samym numerze „TMK”: „Widzewiacy natomiast przygotowywali show z wielką pompą. Ultrasi zbierali pieniążki na oprawę, a na osiedlach organizowano okolicznościowe pochody. Osobne przemarsze zorganizowały m.in. Chojny,

3 Zbigniew Pasek pisze: „Piłka nożna staje się sferą, w której dokonuje się zbawienie pojmowane w zgodzie z orientalnymi koncepcjami soteriologicznymi jako samorozwój, jako etyczne doskonalenie i rozwijanie własnej osobowości” (2012: 110). 
Śródmieście, Stary Widzew (...)”(s. 8). Przytoczone przykłady pokazują że kultura uobecnia się w życiu jej przedstawicieli, którzy dzięki aktom wyrażania, ekspresji odradzają ją raz po raz. Ma to istotny wymiar dla członków tej kultury. „Przeżywanie na nowo odnosi zwycięstwo, gdy wierzymy, że mamy przed sobą ciagłość" (Bruner 2011: 20). Owa ciagłość kultury kibiców wyraża się w słowach: „Byliśmy, jesteśmy, będziemy” (z transparentu „Stomilu” Olsztyn) lub „W naszej opowieści wszystko ma swój porządek - Korona to koniec, rozwinięcie i początek” („Korona” Kielce). Są to dowody na ważność kulturowo definiowanych chronologii - współkonstytuujących z innymi czynnikami tożsamość kibicowskiej kultury.

Ciągłość kultury nie oznacza, że w jej strukturze nie zachodzą zmiany. Struktura społeczna kibicowania zmienia się wskutek komercjalizacji dyscypliny (Antonowicz, Kossakowski, Szlendak 2011), ale interpretacja aktywności kibiców przez pryzmat „performansu” w niniejszym artykule dotyczy kibiców „starego” typu, kibiców „ultras”, którzy wyraźnie się sprzeciwiają przemianom we współczesnym sporcie. Do głosu dochodzi dychotomia „My - Oni”, gdzie „My” oznacza kulturę kibiców, a „Oni” to konglomerat oficjalnych władz piłkarskich i politycznych, świata biznesu i tzw. kibiców „pikników” (niewspierających ruchu ultras, będących „Zwykłymi” kibicami, często nieangażującymi się w aktywne kibicowanie; na temat podziału kibiców zob. Giulianotti 2002). „Ultrasi” są odpowiedzialni za tworzenie performansów na trybunach (oni tworzą oprawy meczowe). „Piknicy” są po prostu fanami drużyny i sportu (interesuje ich jakość widowiska piłkarskiego). Trzecią grupa, najmniej liczną, są , ,chuligani”, czyli grupa „bojowa”, która uczestniczy w konfrontacjach fizycznych, np. ,ustawkach”.

Niezwykle istotną kwestią w przypadku kibiców jest przyjęcie „zobowiązania” wobec widzów i tradycji (Carlson 2007: 37). To pierwsze zobowiązanie związane jest z kluczową rolą ,publicznej demonstracji konkretnych umiejętności” (tamże: 26). Widzowie widowiska sportowego i tego, co prezentują kibice - ultrasi, mają możliwość przeżycia spektaklu, a ci ostatni mają „obowiązek” wywiązania się ze swojej roli. Jednocześnie kibice mają zobowiązanie wobec tradycji, która oznacza wspieranie klubu, jego historii, barw i symboli. W tym sensie analizowanie kibicowskiego performansu jest rodzajem poszukiwania „technik, za pomocą których jednostki w jakiegoś rodzaju zbiorowości wypracowują sposoby gry, które uwierzytelniają równocześnie aktorów i całą grupe" (Abrahams 2011: 55).

Owe zobowiązania, a także użycie „technik”, które wypracowuja „,sposoby gry” uwierzytelniające kibiców i ich wspólnotę, pasują do tego, co na temat performansu („,występu”) pisał Erving Goffman. Analizował „występ” (performance) wielowymiarowo. Chodziło o działalność mającą wpłynąć na innych uczestników interakcji, którzy są publicznością. „Rolą" czy „punktem programu” E. Goffman nazywał ustalony wcześniej wzór działania. Rola zawiera w sobie prawa i obowiązki, może zawierać jedną lub więcej ról granych przy podobnych okazjach i w podobnych okolicznościach przed podobną lub tą samą publicznością (Goffman 1981: 52-53). Performans kibiców zawiera podobne, ,dramaturgiczne” komponenty. Jest on nastawiony na wywarcie wrażenia - na sportowcach własnej (kibice są uważani za „dwunastego zawodnika”) lub przeciwnej (przez „przygniatającą” atmosferę) drużyny. Jest to „pokaz umiejętności” dla kibiców oponentów, ale także dla kibiców swojej drużyny, niezaangażowanych w dopingowanie. To występ dla mediów, włodarzy i opinii publicznej. Rola 
kibiców - performerów - ma swoje obowiązki, ale i prawa. Są one związane z możliwością wyrażania, prezentowania swoich przekonań, treści swojej kultury.

Ta „gra” służy nawiązaniu specyficznych stosunków społecznych i tworzy rodzaj „struktury”, „schematu interpretacji” („ramy”) podczas wydarzeń sportowych. Trudno sobie wyobrazić mecz piłkarski bez kibiców (tak się dzieje, gdy kluby - wskutek kar - zmuszone są rozgrywać spotkania bez udziału publiczności). Ich performanse tworzą atmosferę mająca siłę przyciągania „publiczności”, co przekłada się na wpływy finansowe klubów. Znaczenie performansów kibicowskich objawia się też tym, że są one synchroniczne w aspekcie czasowym oraz monoprzestrzenne (odbywają się w jednym miejscu, np. na stadionie). Taki rodzaj performansów Jacek Wachowski nazywa ,pperformansami pierwszego stopnia” (2011: 174). Siła tych przedstawień jest nierozerwalnie związana z konkretnym miejscem i chwilą.

\section{WSPÓŁCZESNE TŁO, CZYLI PERFORMANS W ŚWIECIE MODERN SPORT}

Współczesny sport stał się zjawiskiem podlegającym komercjalizacji. Stał się ważnym elementem gry ekonomicznej, w którą angażują się podmioty postrzegające go jako platformę finansowych benefitów. Barry Smart uważa, że sport nie jest już sferą niezależną, lecz stanowi jedną z części „złotego trójkąta”, razem z mediami i korporacyjnym sponsoringiem (2007: 114). Nie jest to jednak tylko kwestia sponsoringu, nowych strojów, piłek i butów. Przemiana dotyczy także trybun, gdzie pojawia się nowy fan, ,piknik”, czyli kibic konsument.

„Nowy” kibic nie przyjdzie tam, gdzie nie ma odpowiedniego komfortu, zaplecza i dostępnych atrakcji. Z tego powodu budowane są nowe stadiony, których zarządcy robią wszystko, by zamożniejszy kibic czuł się dobrze. O konsekwencjach „przyciagania” nowych kibiców wspomina Jonas Gabler: „(...) często, by ich przyciągnąć, kluby zmieniają atmosferę meczu w atmosferę zwykłego wydarzenia rozrywkowego. To oznacza zupełnie inny scenariusz widowiska, utrudniający dopingowanie. Podczas przerw w grze leci bardzo głośna muzyka, więc nie słychać śpiewów. Kluby rozdają akcesoria do hałasowania. Czasem konkurują z kibicowskimi choreografiami poprzez umieszczenie flag/banerów z nazwami sponsora. I na koniec często kibice na nowym stadionie nie mają gdzie powiesić swoich flag, bo ich miejsce zajmuje przestrzeń reklamowa. (...) Mówiąc bardziej ogólnie: wcześniej scenariusz meczu był pisany przez grę zawodników i jej interakcję z zachowaniem kibiców. Dziś kluby starają się zawczasu wyreżyserować mecz i zrobić z niego «event», który w ich założeniu będzie bardziej atrakcyjny «dla każdego»"4.

Ów „event” również jest performansem. Jest on instrumentem praktyk systemowych, zogniskowanych wokół głównych osi gospodarki kapitalistycznej. Wykorzystuje się działania performatywne, by uczynić starania ekonomiczne jeszcze bardziej skutecznymi. Jednak pomimo „odmagicznienia” czy zapanowania ,instrumentalnej racjonalności” piłka nożna, jak pokazują antropolodzy i socjolodzy (zob. Jawłowski 2007; Czubaj, Drozda, Myszkorowski

\footnotetext{
4 Wywiad opublikowany na stronie: http:/stadiony.net/aktualnosci/2011/10/niemcy_piekny_stadion_moze_byc_
} rozczarowaniem (dostęp: 06.07.2013). 
2012; Antonowicz, Wrzesiński 2009) jest wciąż substytutem religii, dostarczycielką rytuałów kreujących znaczenie. Jeffrey C. Alexander wspomina: „Praktyczne znaczenia wciąż są strukturyzowane przez poszukiwanie zbawienia. To, jak zostać zbawionym - jak przeskoczyć z przeszłości do teraźniejszości i dalej do przyszłości - pozostaje nadal pilną troską społeczną i egzystencjonalną. Ta pilna potrzeba wytwarza marzenia i mity oraz inspiruje olbrzymie starania na rzecz praktycznej zmiany" (2010a: 97). Jednak, by performans odniósł sukces, musi zostać spełnionych kilka warunków.

Po pierwsze, chodzi o uczynienie „psychologicznej identyfikacji” możliwą, czyli wytworzenie, dzięki sprawnemu i poruszającemu występowi, emocjonalnego związku publiczności z występującymi (i z ich przekazem). Dzięki temu może dojść do „rzutowania kulturowego znaczenia z performansu na publiczność” (Alexander 2010b: 394). Owo „rzutowanie” jest możliwe tylko wtedy, gdy publiczność oceni występ jako prawdziwie odwzorowujący kulturowe „tło”. Aktorzy „sceny” (również ci, którzy przygotowują widowiska na stadionach) stają każdorazowo przed trudnym zadaniem: dokonania połączenia wielu elementów w jedną całość. Nie trudno tutaj o porażkę - ponowne przywołanie składowych performansu przysparza wiele problemów z uzyskaniem autentyczności. Osiagnięcie tej ostatniej komplikuje się przez zmianę struktury „,publiczności” oceniającej performans kibiców. „Nowi” kibice mogą nie rozumieć definicji sytuacji „starych” kibiców, a w konsekwencji uznać ją za anachroniczną i niezgodną z ich „schematem interpretacji”. W konsekwencji o „psychologicznej identyfikacji” może nie być mowy.

Takie „rozłączenie” powoduje, że prościej tworzyć performanse odnoszące się do tożsamości partykularnych raczej niż uniwersalnych. Partykularyzm rodzi kłopot z akceptacją odmiennych performansów; z tego powodu krytyczne oceny kibiców „hardcorowych” komercyjnych widowisk dla „wszystkich”. Komercyjne przedstawienia uznawane są przez „ultrasów” za „sztuczne” i „nieprawdziwe”. Nie czują się w nich reprezentowani, a więc nie dokonuje się - istotna dla legitymizacji performansu - psychologiczna identyfikacja. Najprawdopodobniej wynika to z ważnej roli, którą pełnią opozycje, kulturowe dystynkcje, w celu konstytuowania się tożsamości kibicowskiej wspólnoty. Tam, gdzie granice subświatów wydają się zanikać lub są pozbawiane znaczenia, może pojawić się potrzeba ponownego ustanowienia różnicy. Pomaga w tym performans.

Powstaje specyficzna kontradykcja, podział na dwa światy, dwa style performansu. Z jednej strony mamy do czynienia z kibicami i ich dążnością do pokazu umiejętności w imię pewnej kultury i wartości. Z drugiej strony mamy do czynienia z performansem „w służbie zysku” (Brown 2007: 164). Właściciele klubów, reklamodawcy mogą mieć na uwadze kibiców, ale tylko zawężając ich rolę do takiej, która jest zgodna z polityką biznesową i ekonomicznymi standardami. „Ci, którzy nastawiają się na zysk ekonomiczny uzyskany z nowoczesnego sportu nie są szczególnie związani z tymi, którzy oczekują od niego emocjonalnego lub nawet duchowego spełnienia - czyli z fanami. Nowoczesny kapitalizm kreuje, w sposób nieunikniony, napięcie pomiędzy tymi przywiązanymi do drużyny ekonomicznie, a tymi związanymi w sposób emocjonalny” (tamże). Dla „tradycyjnych” fanów performans komercyjny jest nieautentyczny, choć oczywiście nie są oni jego jedynymi odbiorcami. Pomimo różnic oba typy performansu (,ultras” i komercyjny) są performatywne, ponieważ wywołują reakcję u innego typu widzów. 
Performans na trybunach. O kulturowo-dramaturgicznym aspekcie kibicowania

\section{PERFORMANS KIBICÓW - TRADYCYJNA „RAMA” W NOWOCZESNYCH CZASACH}

Urynkowienie widowisk sportowych stawia przed kibicami „starego” typu wyzwanie. Muszą oni przekonać innych (i siebie w dużej mierze), że ich kultura wciąż ma znaczenie bez względu na przemiany wokół. O tym, że nie jest to łatwe świadczą chociażby dwa fakty. Po pierwsze, mowa jest o „gmatwaninie przedstawień zbiorowych, jakie składają się na kulturę" (Alexander 2010b: 398). Istnieją różne typy kibiców i każda z tych grup na swój sposób uczestniczy w widowiskach sportowych. Po drugie, kibice „starego typu” mają przeciwko sobie władzę społeczną, która nie pochodzi tylko ze sfery publicznej (policja, władze państwowe). Kibice mają przeciwko sobie władzę społeczną „nowego typu” - korporacje, media, reklamodawców, mających coraz większy wpływ na sport. Dodatkowo stosowne regulacje w zakresie formy kibicowania narzucają organizacje zarządzające rozgrywkami - FIFA czy UEFA, które wykluczają możliwość stania podczas meczu czy odpalania rac - a zatem elementów, które dla wielu kibiców tradycyjnych stanowią część definiensu „kibicowania”.

Kibice, którzy jeszcze kilkanaście lat temu mieli właściwie jednego przeciwnika-kibiców drużyny przeciwnej, znajdują się - w bardziej złożonym społeczeństwie - w coraz to nowych opozycjach. Broniąc „prawdziwego” wymiaru bycia fanem przed „fałszywym” (komercyjnym) ustanawiają binarne opozycje. $Z$ tego powodu, choć kulturę kibiców wyznaczają różne aspekty: kody dostarczające analogii, asocjacji, amplifikacji czy kulturowej chronologii, to nie da się ukryć, że w dużym stopniu ich kulturę można byłoby nazwać „,systemem klasyfikacji, składającym się z binarnych przeciwieństw" (Alexander 2010c: 113). Jest to widoczne w strukturze „dramatów”, w których opozycje są przedstawiane pod postacią ,antagonistów, fałszywych i sztucznych aktorów, odgrywających swoje role tylko dla osiagnnięcia własnych interesów” (Alexander 2010b: 391). Przegląd performansów i ich „tekstów” umożliwia weryfikację empiryczną takiego twierdzenia. W dalszej części przedstawiono kilka przykładów „występów” kibiców, w których wyrażają swoją antypatię/opór względem władz różnej maści. Przytaczane przykłady pochodzą m.in. z czasopisma „To My Kibice!” (w nawiasie podano numery i rok wydania pisma).

Znamiennym przypadkiem są hasła prezentowane na transparentach, np. przez kibiców „Legii” Warszawa, którzy swego czasu dawali wyraz swojemu niezadowoleniu z praktyk nowego właściciela klubu - firmy ITI. W 2008 można było obejrzeć transparent składający się z wielkiego obrazu, na którym dwóch kibiców „rozdziera” logo sponsora „ITI”. Litera „T” w kolorze pomarańczowym w pewnej chwili „pęka”, transparent jest rozciagany w obie strony, wskutek czego z litery „T” wyłania się obrazek dwóch dłoni trzymających w środku serce. W samym jego środku widnieje duże logo klubu. Cały performans polegał zatem na tym, by pokazać, że siła kibiców potrafi „,wydobyć” spod komercji „głębię” wartości symbolicznych. Potwierdza to zresztą tekst będący dodatkiem do transparentu: „Nasza pasja, która nie ma końca. Siła miłości niszczy siłę pieniądza” („TMK” 08/2008).

Inne przykłady sprzeciwu wobec - zbyt silnych zdaniem kibiców - restrykcji to np. hasła „150 zakazów. Nigdy nas nie zniszczycie” (kibice „Górnika” Łęczna, nr 12/2009). Wielką „sektórówkę” przedstawili także fani „Korony” Kielce. Widniało na niej hasło: „Rewolucja jest 
blisko, wyjdziemy na ulicę, bo przecież wszystko ma swoje granice". Napisowi towarzyszyło hasło „Revolt” i ogromna postać kibica stojącego na tle herbu klubowego szykującego się do rzucenia racą świetlną (nr 06/2011). Symboliczny wynik konfrontacji pomiędzy kibicami a światem polityki przedstawiała oprawa fanów „Śląska” Wrocław w maju 2013. Była to choreografia z namalowaną sceną walki bokserskiej. Na „deskach” leżała postać w garniturze i krawacie, a w narożniku, z wzniesionymi ramionami w geście triumfu, widoczna była postać zwycięzcy. O tym, że to kibic przekonuje napis na plecach boksera - „Wielki Śląsk” (to nazwa stowarzyszenia kibiców wrocławskiej drużyny). Sektorówkę podsumowywał również wielki napis pod obrazkiem: „Polityka nie pokona fanatyka” („TMK” nr 6/2013). Liczne w ostatnim czasie były performanse kibiców kierowane przeciwko władzom politycznym, szczególnie premierowi Donaldowi Tuskowi. Oprócz haseł, które pojawiały się w prostej formie (np. „Idę na wybory, nie głosuję na Donka” - „Legia”; „Niespełnione rządu obietnice. Temat zastępczy - kibice” - „Lech” Poznań; „Teraz Usłyszycie Same Kłamstwa” - „Lech”, podkreślenie oryginalne - przyp. RK), pojawiały się także bardziej wymyślne performanse, jak choćby ten przygotowany przez ultrasów „Zagłębia” Sosnowiec, w którym kibice trzymają w dłoniach race świetlne i mają założone na twarzach maski z wizerunkiem premiera polskiego rządu. Kibice z Sosnowca, zakładając maski i odpalając race (ich odpalanie jest zabronione na stadionie), stawiaja polityka w dwuznacznej sytuacji. Innym przykładem, który w nieco metaforyczny sposób przedstawia krytykę polityki, jest transparent kibiców „Górnika” Zabrze: „Piłkarze! Od dziś strzelajcie przed przerwą - nigdy PO” (nr 11/2011). Słowo „PO” jest pogrubione, wyróżnione czerwonym kolorem.

Treść emblematów wskazuje, że kibice starają się wyłamać ze schematów pragmatyki kulturowej proponowanej przez władze polityczne czy siły rynkowe. Władza społeczna ripostuje w różny sposób, choćby przez nakładanie zakazów stadionowych, co jest karą drastyczną, ponieważ uniemożliwia aktorom odegranie jakiegokolwiek występu. Władze mogą także manipulować przy „,́rodkach produkcji symbolicznej”, np. cenzurować materiały wprowadzane na stadion. Stużby porządkowe rekwirują materiały pirotechniczne, flagi, które przekraczają dozwolone wymiary lub propagują treści niezwiązane z meczem (oszacowanie treści pozostaje w gestii służb). W marcu 2013 kibicom „Ruchu” Chorzów nie pozwolono wnieść oprawy na mecz w Kielcach z „Koroną”, choć jak przekonuje relacja w „TMK” (nr 4/2013) oprawa była przygotowana zgodnie z regulaminem stadionu (służby porządkowe były innego zdania). Trudno rozstrzygnąć, kto miał rację w sporze. W numerze 10/2011 „TKM” zaprezentowano zdjęcia przecinania flagi narodowej kibiców z Wodzisławia Śląskiego zmierzających na mecz kadry narodowej z Niemcami. Na meczu ligowym „Lechii” Gdańsk z „Górnikiem” Zabrze (obserwacja własna) spiker - na polecenie obserwatora z Polskiego Związku Piłki Nożnej nakazał zdjęcie transparentu zawierającego treści niezwiązane z meczem (chodziło o hasło „17.09.1939 - Czwarty Rozbiór Polski”). Powyższe performanse bez wątpienia „zaburzały równowagę" (Wachowski 2011: 263), stając się na wskroś antysytemowe, uciekając przed komercyjną modernizacją futbolu.

W wyniku komercjalizowania się piłki nożnej rodzą się paradoksy. Performanse tworzone przez speców od marketingu wydają się nie spełniać w stu procentach potrzeby „realizmu” i ,autentyczności”, czego dowodem był chociażby mecz towarzyski Polska - Niemcy, podczas którego nie udało się zorganizować odpowiedniego poziomu dopingowania. Zabrakło tych, 
którzy produkcję „dramatu” dopingowania znają najlepiej - „tradycyjnych” kibiców (którzy w grupkach byli na stadionie, ale bojkotowali oficjalne zamiary władz). Doping się nie „kleił”, był chaotyczny, różne sektory stadionu nie dopingowały Polaków w zsynchronizowany sposób.

Paradoks ten opisuje teoria Ervinga Goffmana, który nadał niezwykłe znaczenie zjawisku „występowania” przed publicznością. Performanse kibiców są swoistym tworzeniem „ram”, czyli organizowaniem doświadczenia, nadawaniem znaczenia „czemuś, co inaczej stanowiłoby pozbawiony sensu aspekt danej sceny” (Goffman 2010: 21). Każdy aspekt kibicowania wpisuje się w swoistą „ramę”, zgodnie ze znaczeniem, które jest uformowane kulturowo. Nawet najdrobniejsze elementy składają się na coś, co E. Goffman nazywał „centralnym składnikiem kultury" danej grupy społecznej (tamże: 25). Taka konstatacja jest bliska tezie J.C. Alexandra, że wszystkie aspekty performansu muszą się „zejść”, by on sam osiągnął sukces. W „kulturze kibiców” każda czynność jest istotna i dba się o jej autentyczność. Próby przemiany „starego” typu kibicowania w „nowy” są próbą ustrukturyzowania urywków doświadczenia, poszczególnych czynności w nowy sposób, w nowej „ramie”. Mamy do czynienia ze stworzeniem nowego sposobu organizacji doświadczenia „kibicowania”, pozostającego w referencji do nowych treści kulturowych.

W przypadku kibiców „fanatycznych” na „centralny składnik kultury” składa się powiązanie kilku klas schematów: analogie, antypatie/opozycje, chronologie. „Rama rynkowa” nadaje zachowaniom kibiców inne znaczenie - dobrej zabawy, konsumpcji, braku „wrogów” i hierarchii. Jeżeli da się w niej wyodrębnić jakąkolwiek stratyfikację, to jest ona nieoficjalna. Oficjalnie każdy może być kibicem, animozje międzyklubowe nie mają znaczenia. Barwy przeciwnych drużyn mają dla rynkowych graczy sens taki, że wymagają nieco innego procesu produkcji szalików, proporczyków, koszulek. O ile w „tradycyjnym” kibicowaniu podziały przebiegają w oficjalny sposób (wiadomo z kim jest „kosa”, a z kim ,zgoda”), to w wydaniu rynkowym stratyfikacja jest związana $\mathrm{z}$ dostępem do gadżetów, kas biletowych i wszelkich dóbr, w przypadku których niezbędny jest zasobny portfel. Performans „ultrasów” dotyczy wartości kulturowych związanych z symbolem klubu, niekiedy dotyczy antagonizmów5

\section{PERFORMANS KIBICÓW „TRADYCYJNYCH”- SYMBOLE WŁADZY I ANTAGONIZMÓW}

Jakiego rodzaju wpływem dysponują kibice w zmieniającym się środowisku współczesnego sportu? Wydaje się, że ów wpływ ogranicza się właściwie tylko do symbolicznych gestów, wyrażających sprzeciw wobec następujących wydarzeń. Kibice nie mają oparcia

\footnotetext{
Pomijam w tekście bardzo ekstremalne przykłady agresywnych „performansów” kibiców, opartych na fizycznych konfrontacjach z kibicami przeciwnych drużyn. W niektórych przypadkach dążność do fizycznej konfrontacji odsuwała na plan dalszy kontekst sportowy (wydarzenia na boisku). Liczne przykłady takich agresywnych „performansów” odnaleźć można w pamiętnikach angielskich (Pennant 2009; King, Knight 2008; King, Knight 2010) i polskich kibiców (Zieliński 1993, 1997). Przemoc fizyczna jest rugowana ze współczesnych stadionów, głównie za pomocą zaostrzonego prawa (ustawa o bezpieczeństwie imprez masowych), monitoringu i wprowadzenia imiennych kart kibica. Wszystko to łączy się ze zjawiskiem stadionowego „chuligaństwa” (Frosdick, Marsh 2005).
} 
instytucjonalnego, brak znaczących osób, które zabiegałyby o ich interesy . W związku z tym ich reakcja ogranicza się właściwie tylko do „pokazu umiejętności” w sferze ,środków produkcji symbolicznej”. Tutaj pozostał ostatni bastion „wolności”, która, choć ograniczana przez wszelakie władze, jest wyrażana w występach scenicznych. To powoduje, że pewne elementy performansu kibiców wciąż mogą spontanicznie się pojawiać na przekór oficjalnym czynnikom. Przykładem jest bez wątpienia przedstawienie kibiców „Legii”, którzy na meczu z izraelskim zespołem „Hapoel” Tel Aviv zaprezentowali gigantyczną w rozmiarach oprawę przedstawiającą zakrytą twarz w kominiarce z ogromnym hasłem: „Jihad Legia”. To istotny przykład „zaburzenia równowagi”, gdyż europejskie władze piłkarskie wyraźnie oddzielaja kwestie polityczne, światopoglądowe od rozgrywek.

Ukazywanie własnej grupy w kategoriach odrębności, alternatywy, a nawet lekceważenia i pogardy wobec innych grup, konstytuuje tożsamość kibiców. To nie oznacza, że ta tożsamość nie jest współkonstytuowana przez bardziej afirmatywne wartości. Są one również widoczne w performansach. Nietrudno się jednak zgodzić z Jeffreyem Alexandrem, że: „Antagonizm jest kluczowy dla fabuły każdego udanego performansu” (2010b: 430). Przeciwieństwa „iskrzą”, wywołują napięcie zarówno u aktorów widowiska, jak i jego odbiorców.

„Władza” kibiców manifestowana jest na transparentach i w trakcie pokazów. Kibice mają możliwość prezentowania opraw, w których przyznają sobie prawo do „rządzenia”, przede wszystkim w wymiarze geograficznym (na danym „terenie”), ale i symbolicznym. W pierwszym przypadku nierzadko dotyczy to miasta, w którym rywalizują różne drużyny. Rywalizacja o „władzę” w mieście osiaga punkt kulminacyjny w czasie bezpośrednich konfrontacji, czyli tzw. „derbów”. W Warszawie dominację nad „Legią” podkreśla „Polonia” Warszawa: „Polonia to historia i stolicy duma. Was by nie było, gdyby nie komuna” (,TMK” nr 10/2011). O dominacji wspominają w haśle na transparencie kierowanym do fanów „Ogloopolu” kibice „Wisłoki” Dębica: „Nasza propaganda jest jasna. My jesteśmy siłą tego miasta” („TMK” nr 11/2011). W Krakowie rywalizuja „Cracovia” i „Wisła”. Kibice tego pierwszego klubu zaprezentowali transparent „Cracovia. Władcy Miasta Królów” („TMK” 12/2010).

Performanse kibiców wykraczają poza granice miasta, prezentowane treści mogą dotyczyć większych regionów. Kibice „Arki” Gdynia: „To MY reprezentanci lepszej strony Trójmiasta” (,TMK” nr 10/2010). Gdynianie rywalizują z „Lechią” Gdańsk nie tylko o prymat w Trójmieście, ale na całym terenie Pomorza. Miało to swoje konsekwencje w praktyce, kiedy kibice z Gdańska zdobyli wielki transparent rywali z napisem „Władcy Północy” (w barwach „Arki”). $\mathrm{Na}$ kolejnych derbach (w 2007 roku) powiesili go do góry nogami na płocie, a następnie podpalili. Obecnie na meczach „Lechii” jest widoczny duży transparent „Władcy Północy” w barwach gdańskiego klubu. Innym przykładem symbolicznego zamanifestowania swojej lokalnej tożsamości jest transparent „Strażnicy Bramy Pomorza” zaprezentowany przez kibiców „Chojniczanki” Chojnice (II liga, „TMK” nr 11/2011).

Kibice często posiłkują się metaforyką „władczą”, podkreślającą pewną tęsknotę za sławą ich klubu. Hasła, takie jak: „Nasze są całe Bieszczady. Nikt tutaj nie da nam rady” („Sanovia” Lesko, „TMK” nr 12/2009), mogą być rozpatrywane nie tylko jako dążenie do dominacji nad lokalnym rywalem, ale także jako element określający regionalną tożsamość. W pewnym sensie slogan „nasze są całe Bieszczady” to stwierdzenie będące afirmacją 
tożsamości - „władcami” Bieszczad mogą być przecież tylko ci, którzy stąd się wywodzą, mają tutaj korzenie i którym zależy, by żadna „obca” tkanka tego zmieniła. Takie zwroty trudno jednak uznać za „perlokucyjne”, mające przywilej kreowania rzeczywistości (Austin 1993). To raczej zwroty „illokucyjne”, oddziałujące na emocje, myśli, ale niewywołujące $\mathrm{w}$ istocie zmian w strukturze społecznej.

Jaką bowiem konsekwencję praktyczną może mieć hasło na transparencie „Naród WYBRANY - Cracovia Pany"? Kogo może przekonać treść takiego performansu? Przeciwników z opozycyjnej trybuny? „Pikników”? Zapewne jest to gra symboliczna wpisująca się w budowanie wspólnotowej tożsamości. Aby zrozumieć sens takich przekazów, warto powrócić do tezy Victora Turnera, który zauważył, że performanse należą do trybu ,przypuszczająco-spełniającego”, wyrażającego nadzieję, a nie stwierdzającego fakt: „na chwilę możliwe jest niemal wszystko: następuje zawieszenie tabu, uruchomienie fantazji, wywyższenie ubogich i poniżenie możnych, zachowanie właściwe trybowi oznajmującemu zostaje całkowicie odwrócone” (2009: 43). W takich chwilach pojawia się ,wyłom” w strukturze - stan liminalny, w którym członkowie wspólnoty mogą pozostać niezależni względem czynników stratyfikujących.

Gdy kibice „Legii” Warszawa wywiesili podczas meczu w Krakowie (na stadionie „Wisły”) transparent „Klub nad Wisłą”, to nie chodziło im o stwierdzenie faktu (Warszawa leży nad rzeką Wisłą), lecz pokazanie swojej wyższości nad przeciwnikiem. Performans ma pokazać moc i siłę sprawczą odgrywających, „kategoria «My» musi być potężna, w przeciwnym razie tożsamość społeczna nie zapewnia jednostce satysfakcji” (Bauman 2012: 49). Wiele kontrowersji wywołało hasło: „Bóg wybacza - Cracovia nigdy”, które jednoznacznie skrytykował kapelan krakowskiego klubu ks. Henryk Surma: „Pytam wykonawców tego transparentu i zwracam się do was z życzliwością: co ma znaczyć ten transparent? Co to za przesłanie? Czy to jest przesłanie na miarę człowieka, jeśli zawiera treści nienawiści, agresji i przemocy? (...) Ten napis zakłóca dobrą atmosferę na stadionie i jest sprzeczny sam w sobie. $\mathrm{Z}$ jednej strony Bóg, który jest miłością, przebacza każdemu, kto się chce nawrócić, a druga część zdania to Cracovia, która nie przebaczy nigdy”6. „Schemat interpretacji”, w jakiej się owo hasło pojawia, nie jest jednoznaczny, o czym świadczy komentarz innego kibica „Cracovii”, pisarza, Jerzego Pilcha: „Jest to hasło potężne. Mistrzowskie stylistycznie, otchłanne metafizycznie; lakoniczne jak przystało boiskowemu zawołaniu i gęste jak przystało linijce wielkiej poezji. Ponieważ jest wielkie - jest też - ma się rozumieć - ryzykowne, a nawet niebezpieczne. Prawdziwe wzloty ducha nigdy nie są bezpieczne. Można je - jak wszystko - rozumieć i interpretować trywialnie. Można głęboko"7.

Publiczności takiego „występu” pozostaje zdecydować o autentyzmie i znaczeniu przekazu, a w konsekwencji o wadze „kulturowego tła”. W kontekście powyższych rozważań, transparent „Pasów” (potoczne określenie „Cracovii”) odgrywa istotną rolę, gdyż pomaga skupić się na „,analogiach” (i „,chronologiach”), które pojawiają się w performansach kibiców.

\footnotetext{
${ }^{6}$ Cytat pochodzi ze strony internetowej http://www.wikipasy.pl/B\%C3\%B3g_wybacza_-_Cracovia_nigdy (30.01.2014)

7 http://www.wikipasy.pl/B\%C3\%B3g_wybacza_-_Cracovia_nigdy\#Jerzy_Pilch ( 30.01.2014).
} 


\section{PERFORMANSE WIERNE HISTORII, TRADYCJI I WARTOŚCIOM}

Performanse kibicowskie są twórcze, częstokroć wykorzystują parafrazę, czasem trawestację. Prezentacje fanów sportowych często nasycone są ironią czy wykorzystują parodiowanie Jednak w przypadku religii, wierności pewnym ideałom trudniej natrafić na prześmiewcze akcenty. Przykładów odniesień, analogii do sfery świętej na trybunach nie brakuje. Kibice „Chrobrego” Głogów prezentowali transparent „Wyznawcy pomarańczowej religii” (w barwach klubu dominuje ten kolor). Kibice „Rakowa” Częstochowa zaprezentowali treść: „Raków - The Religion. Tu jest nasza świątynia - Limanowskiego 83” (adres klubowego stadionu). Bardzo wiele podobnych przykładów pokazują D. Antonowicz i Ł. Wrzesiński w swej analizie kibiców jako wspólnoty niewidzialnej religii (2009).

Natomiast kibice „Legii” Warszawa odwołali się do sił wyższych z „prośbą” o „pomoc”. Zaprezentowali - ogromny w skali - obraz, w którego centrum znajduje się głowa Chrystusa (z koroną cierniowa). Obok znajduje się sformułowanie: „Boże Chroń Fanatyków” („TMK” nr 11/2010). Kibice tego samego klubu poszli jeszcze dalej w wykorzystaniu języka kultury religijnej. Na kończącym sezon 2012/2013 meczu ze „Śląskiem” Wrocław przygotowali performans, który włączył wszystkich kibiców (oprócz fanów gości) w swoje ramy. Cały stadion został „przybrany” w kolorach klubu, każdy kibic na stadionie, również na sektorach „niezaangażowanych” współtworzył performans, machając balonem. Na trybunie „Żyleta” (sektor ultras) zaprezentowano zaś choreografię, której głównymi składowymi było hasło „Habemus Campione” oraz logo klubu zapisane tak, że przypomina herb Watykanu. W tym przypadku widzowie stali się funkcjonalni, zostali włączeni w akt performatywny, natomiast on sam pokazał, że kibice potrafią przekroczyć w swej twórczości światy i wykorzystać metaforykę oraz symbolikę religijną w kulturowym mimesis.

Do sakramentu małżeństwa odwoływali się kibice „Korony” Kielce, prezentując oprawę z tekstem „...oraz, że Cię nie opuszczę aż do śmierci”. Nad nim wielkie płótno z wymalowaną ręką trzymającą małe pudełeczko $\mathrm{z}$ obrączką w środku. Obraz jest skierowany w stronę murawy, co zapewne miało na celu wskazać, że propozycja miłości aż do śmierci dotyczy klubu ${ }^{8}$. Intrygującą treść, w sensie dostępnych możliwości interpretacyjnych, zaprezentowali kibice „Ruchu” Chorzów transparentem „Świat bez Ruchu to chaos” („TMK” nr 10/2011). Tego rodzaju występy potwierdzają tezę Jeffreya Alexandra o tym, że również współcześnie ludzie poszukują „zbawienia”. Bez klubu świat pozbawiony byłby porządku.

Religijne analogie nie są jedynymi w przedstawieniach kibiców. Zdarzają się zapożyczenia ze świata kultury popularnej. „Legioniści” korzystają z piosenki Czesława Niemena „Sen o Warszawie”, która stała się hymnem kibiców tego klubu. Na stadionie prezentowany jest także w ogromnej skali obraz z parafrazą tekstu piosenki „Miasto moje a w nim... Legia

\footnotetext{
8 O wiele dalej w swym performansie poszli kibice maltańskiego klubu Valletta FC. Po zdobyciu mistrzostwa Malty organizują oni wielotysięczną fiestę, która, jak dowodzą Gary Armstrong i Jon Mitchell (2006), przejęła rolę dawnego cyklicznego karnawału na tej wyspie. Po zdobyciu mistrzostwa kraju urządzają także oni ,pogrzeb” swoim największym ligowym rywalom. W tym performansie jest wszystko, co „normalny” pogrzeb zawiera. Jest ksiądz (przebrany kibic), jest pochód, a przede wszystkim są trumny w barwach wrogich klubów. Symbolicznym „pochówkiem” jest roztrzaskanie trumien w drzazgi. Jak widać antypatie i analogie są elementem kultury kibiców pod różnymi szerokościami geograficznymi.
} 
Warszawa”. Obok syrenka, Kolumna Zygmunta, most, Zamek Królewski, Pałac Kultury i nowoczesny wieżowiec. Oprawa wydaje się przedstawiać kulturę kibicowską jako sferę łączącą tradycję z nowoczesnością. Natomiast po wytwór „kultury wyższej” sięgnęli kibice „ŁKS” Łódź („TMK” nr 11/2011), którzy zaprezentowali oprawę wykorzystującą motyw z obrazu Krzyk Edvarda Muncha. Na dole oprawy znajduje się trzynaście postaci jakby „wyjętych” z obrazu norweskiego malarza (człowiek trzymający się za głowę), które mają na piersi herby wrogich klubów i które trawi ogień od spodu. Nad „ofiarami” znajduje się obraz kibica „ŁKS” z wystawionymi do walki pięściami. Całość wieńczy napis „Nie znacie dnia ani godziny” (czcionka „ociekająca” krwią”). Z performansu łódzkich fanów wynika zapewne, że cierpienie to stan, który czeka kibiców przeciwnych drużyn. Jakkolwiek nie traktować prezentacji łodzian, trzeba przyznać, że wykazali się dość specyficznym potraktowaniem dzieła sztuki. Dokonali „transpozycji” motywu artystycznego, podtrzymując element „,ierpienia” zawarty w pierwowzorze, zmieniając tylko jego metaforyczny wymiar.

Kibice „Legii” Warszawa na meczu wyjazdowym z „PSV” Eindhoven zaprezentowali zmodyfikowaną wersję reklamy jednego z producentów piwa. Zachowano stylistykę i barwy reklamy (zielone tło i biała czcionka), z tym że zamiast hasła „Probably the best beer in the world” wskazali: „Probably the best fans in the world”. W środku znajdował się „kapsel”, na którym w oryginale znajduje się logo „Carlsberg Beer”, natomiast na meczu widoczny był napis „Legia”. Mamy tutaj do czynienia z „transpozycja” (Goffman 2010) „ramy pierwotnej” (reklama piwa) i wykorzystaniem jej do zamanifestowania innego znaczenia. Taką transpozycję można uznać za rodzaj konsumenckiej kreatywności, gdy towar będący wytworem reklamy staje się modelem do dowolnej transformacji i wykreowania własnego znaczenia. Producent piwa jest kojarzony z piłką nożną (m.in. sponsorował Euro 2012), zapewne większość kibiców na piłkarskich stadionach Europy rozpoznaje jego logo, co kibice „Legii” mogli wziąć pod uwagę. Starannie wypromowana marka i logo stały się „ofiarą” swobodnej gry interpretacyjnej w performansie polskich kibiców.

Metaforę plasującą się pomiędzy wytworami kultury konsumpcji a sprzeciwem wobec komercjalizacji piłki nożnej zaprezentowali kibice „Widzewa” Łódź podczas derbów z „ŁKS”: „Wzdłuż trybuny rozwinięto płótno będące imitacją racy z napisem: «Best Before 08.06.2012», czyli «najlepiej użyć przed»... i tu data nieprzypadkowa, czyli termin inauguracji przyszłorocznego Euro (...)"9. Ten przykład ma dowieść, że kibicowanie miało największą wartość „odżywczą” przed rozpoczęciem Euro 2012, gdyż podczas imprezy dominowała „rama” rynkowa, a na trybunach zasiedli kibice konsumenci. Performans kibiców z Łodzi jest znamienny, pokazuje, że fani „tradycyjni”, choć odwołujący się do „starych, dobrych czasów", sięgają po język rodem z kultury późnego kapitalizmu. To kolejny dowód na zmiany przenikające stadiony oraz na to, że te zmiany wymuszają u kibiców „konserwatywnych” prezentowanie tradycji w nowych ramach. Nie oznacza to jednak, że rezygnuje się z haseł i metafor ugruntowanych w historii. Kibice „Widzewa” prezentują często na spotkaniach transparent ze słynnym hasłem „You'll Never Walk Alone”, kojarzonym z hymnem klubu FC Liverpool (piosenka pochodzi z musicalu z 1945 roku, a utwór wykonywał m.in. Frank

\footnotetext{
9 http://fcpabianice.widzewtomy.net/index.php?option=com_content\&view=article\&id=155:relacja-z-meczuwidzew-od-ks-17102011\&catid=6:aktualnoi\&Itemid=2 (08.07.2013)
} 
Sinatra). Motto jest zresztą wykorzystywane przez kibiców wielu klubów jako dowód na silne więzi łączące wspólnotę na trybunach.

Odniesienia do tradycji są cechą szczególną kibiców „ultras” i często wyraża się w ich performansach. Wspomnienia istotnych dat, ważnych postaci ze świata sportu (piłkarze legendy itp.) są uzupełniane przez wyrażanie szacunku do wydarzeń spoza dziedziny sportu, np. powstanie warszawskie, strajki Solidarności, odzyskanie niepodległości. Kontekst istotnych wydarzeń dla historii miasta Gdańsk i całego kraju jest widoczny w oprawach kibiców „Lechii”, którzy prezentują m.in. takie hasło: „Znani ze swej wierności. Kibice kolebki Solidarności” („TMK” nr 3/2009). Kibice „Lechii” mogą się poszczycić silnym zaangażowaniem w działalność antysystemową w latach 80. ubiegłego wieku (Wąsowicz 2006, Kossakowski 2011).

Fani wielu klubów podkreślają rolę historii i wierności barwom klubowym: „Olimpia Elbląg. Ponad pół wieku wiary, miłości i walki”; „80 lat zwycięstw i klęsk. Wszystko dla Ciebie Arko”; „65 lat naszej dumy i wiary” („Górnik” Wałbrzych); „Sto lat za nami, kolejne wieki przed nami” („ŁKS” Łódź). Inny wymiar mają performanse, w których ważna jest historia klubu oraz jego rola w życiu kibiców. W niektórych przypadkach performanse dotykają niemalże sytuacji granicznych, w których przywiązanie do klubu odnosi się do sensu życia (i śmierci?) kibiców: „Po życia kres” („GKS” Bełchatów), „Całe życie - Piast Gliwice”. Istotność kibiców dla trwania tradycji klubowej zaprezentowali fani „Zagłębia” Lubin, przedstawiając wielką mapę Dolnego Śląska (wzorowaną na starych mapach z wieków dawnych) z zaznaczonymi fanklubami w różnych miastach i drogami dojazdowymi do Lubina. Rysunek uzupełniało zdanie: „Tradycja nie zginie. Póki my żyjemy”.

\section{PODSUMOWANIE}

Jak starałem się pokazać, kibice próbują przedstawić znaczenie swojej kultury przez performans, nadając swym czynnościom stosowną „ramę”, którą prezentują szerszej publiczności. Ta ostatnia dokonuje oceny autentyczności „występu”, co jest kluczem do uznania go za sukces. Ogromne zróżnicowanie gustów, znaczeń i „ram” powoduje, że zarówno performer, jak i odbiorca mogą funkcjonować w innych realiach kulturowych, co może być źródłem nieporozumień, a nawet konfliktu. Jeszcze kilkanaście lat temu, kibicowanie na stadionach było przede wszystkim kibicowaniem „starego” typu. Bycie fanem oznaczało rodzaj przynależności do pewnej wspólnoty, a większość kibiców niczym się od siebie nie różniła, wywodząc się - w znacznym stopniu - z podobnych środowisk i klas społecznych. Obecnie, obok najbardziej fanatycznych kibiców, dzierżących flagi, transparenty, mentalnie tkwiących w dawnych czasach, pojawia się coraz więcej kibiców nowego typu. Są oni jednostkami przystosowanymi do warunków kultury późnego kapitalizmu: indywidualnego wyboru, konsumpcji, szukania rozrywek również w sferze publicznej. Współczesny stadion jest takim miejscem - przypomina galerię handlową, można tutaj skorzystać z wielu atrakcji, a dodatkowo istnieje realne prawdopodobieństwo przeżycia silnych emocji.

Zjawisko kibicowania można analizować dzięki różnym schematom interpretacyjnym. Każda „rama”, czyli to, jakie dana czynność ma znaczenie, wykorzystuje inne kulturowe tło, odwołuje się do innych wartości. Performanse „ultrasów” tworzą własną „ramę” znaczeniową, 
wykorzystując opozycje, antypatie, analogie i chronologie. Ich występ łączy kulturowo-dramaturgiczna perspektywa. Prezentują pewien system wartości („kultura kibicowska”) w sposób niezwykle ekspresyjny i dramaturgiczny, często wykorzystując zaskoczenie, zwrot akcji, grę światła i dymu odpalonych rac. Wszystko po to, by ich przekaz nadal był w „grze”, by kultura, którą reprezentuja, nadal była jednym z obowiązujących schematów interpretacji na stadionach. To, czy ich performanse okażą się skuteczne, czy zostaną uznane za prawdziwe, a więc czy pozwoli się na legitymizację ich „kulturowego tła”, zależy nie tylko od ich wykonawców, ale w dużej mierze od przychylności sił, na które kibice „starego” typu nie mają już właściwie wpływu.

\section{BIBLIOGRAFIA}

Abrahams, Roger D. 2011. Doświadczenie zwyczajne i niezwykte, w: E.M. Bruner, V.W. Turner (red.), Antropologia doświadczenia, Kraków: UJ, s. 55-82.

Alexander, Jeffrey C. 2010a. Znaczenia życia (społecznego). O źródłach socjologii kulturowej, w: tegoż, Znaczenia społeczne, Kraków: Nomos, s. 91-97.

Alexander, Jeffrey C. 2010b. Pragmatyka kulturowa: performanse społeczne między rytuałem a strategia, w: tegoż, Znaczenia społeczne, Kraków: Nomos, s. 367-422.

Alexander, Jeffrey C. 2011. Mocny program socjologii kulturowej, w: tegoż, Znaczenia społeczne, Kraków: Nomos, s. 99-116.

Antonowicz, Dominik, Radosław Kossakowski i Tomasz Szlendak. 2011. Ostatni bastion antykonsumeryzmu? Kibice industrialni $w$ dobie komercjalizacji sportu, „Studia Socjologiczne" 3: 113-139.

Antonowicz, Dominik i Łukasz Wrzesiński. 2009. Kibice jako wspólnota niewidzialnej religii, „Studia Socjologiczne” 1:115-148.

Armstrong, Gary i Jon Mitchell. 2006. Six Trophies and a Funeral: Performance and Football in the City of Valletta, „City\&Society” 2: 180-206.

Bartmański, Dominik. 2010. Paradoksy socjologii. Kilka uwag o znaczeniu i odbiorze dziet Jeffreya Alexandra, w: J.C.Alexander, Znaczenia społeczne, Kraków: Nomos, s. XIIIXXVI.

Bauman, Zygmunt. 2012. Kultura jako praxis, Warszawa: PWN.

Brown, Sean. 2007. Introduction: Commonality Amongst Diversity: Modernization and Soccer Fans. ,Soccer\&Society” 2-3, s. 163-168.

Bruner, Edward M. 2011. Przeżycie i jego ekspresje, w: V.W. Turner (red.), Antropologia doświadczenia, Kraków: UJ, s. 11-39.

Carlson, Marvin. 2007. Performans, Warszawa: PWN.

Czubaj, Mariusz, Jacek Drozda i Jakub Myszkorowski. 2012. Postfutbol. Antropologia piłki nożnej, Gdańsk: Katedra.

Czyżewski, Marek. 2010. Analiza ramowa, czyli „,co tu się dzieje?”, w: E. Goffman, Analiza ramowa, Kraków: Nomos, s. VII-XLVII.

Duda, Artur. 2011. Performans na żywo. Jako medium i obiekt mediatyzacji, Toruń: UMK. Frosdick, Steve i Peter Marsh. 2005. Football Hooliganism, Cullompton: Willan Publishing. 
Goffman, Erving. 1981. Człowiek w teatrze życia codziennego, Warszawa: PIW.

Goffman, Erving. 2010. Analiza ramowa, Kraków: Nomos.

Giulianotti, Richard. 2002. Supporters, Followers, Fans and Flaneurs. A Taxonomy of Spectator Identities in Football, ,Journal of Sport and Social Issues” 1: 25-46.

Jawłowski, Albert. 2007. Święty ład. Rytuat i mit mundialu, Warszawa: WaiP.

King Martin i Martin Knight. 2008. Hoolifan, Brak miejsca wydania: Trolsen communicate!

King, Martin i Martin Knight. 2010. Niesforne lata 90., Brak miejsca wydania: Trolsen communicate!

Kolankiewicz, Leszek. 2005. Ku antropologii widowisk, w: A. Chałupnik, W. Dudzik, M. Kanabrodzki, L. Kolankiewicz (red.), Antropologia widowisk. Zagadnienia i wybór tekstów, Warszawa: UW, s. 9-32.

Kosiński, Dariusz. 2012. Wieczór w teatrze marzeń. Uwagi o (nie)teatralności piłki nożnej, „Konteksty. Polska Sztuka Ludowa”3-4: 93-100.

Kossakowski, Radosław. 2011. Solidarność na zielonej murawie, w: K. Ciechorska-Kulesza, P. Łuczeczko (red.), Kultura ,, Solidarności”. Socjologiczno-antropologiczne analizy kulturowego dziedzictwa „Solidarności”, Pszczółki: Orbis Exterior, s. 343-358.

Kubikowski, Tomasz. 2007. Performans wedtug Marvina Carlsona, w: M. Carlson, Performans, Warszawa: PWN, s. 6-15.

Leszczyńska, Katarzyna i Katarzyna Skowronek. 2012. Wolność i wierność. O roli „zwrotów” w humanistyce i naukach społecznych, w: K. Skowronek, K. Leszczyńska (red.), Performatywne wymiary kultury, Kraków: Libron, s. 9-25.

Łuba, Dagmara. 2012. Kibice jako choreutai. Masowe performance kibiców KKS Lech Poznań, w: J. Ciechowicz, W. Moska (red.), Futbol w świecie sztuki, Gdańsk: UG, s. 462-473.

MacAloon, John J. 1984. Introduction: Cultural Performances, Culture Theory, w: J.J. MacAloon (red.), Rite, Drama, Festival, Spectacle: Rehearsals toward a Theory of Cultural Performance, Philadelphia: Institute for the Study of Human Issues, s. 1-13.

Mosz, Jakub. 2009. Estetyczne i kulturowe aspekty działalności stadionowych grup ultras, w: T. Sahaj (red.), Pogranicza współczesnego sportu. Ujęcie społeczne, Poznań: AWF, s. $143-165$.

Pasek, Zbigniew. 2012. Jakie zbawienie daje Cracovia? Duchowo-transgresyjny wymiar piłki nożnej, „Konteksty. Polska Sztuka Ludowa” 3-4: 104-114.

Pennant, Cass. 2009. Congratulations. You have just met the I.C.F (West Ham United), Brak miejsca wydania: Trolsen communicate!

Reed, Isaac. 2006. Social dramas, shipwrecks, and cockfights: conflict and complicity in social performance, w: J. Alexander, B. Glesen, J. Mast (red.), Social Performance. Symbolic Action, Cultural Pragmatics, and Ritual, Cambridge: University Press, s. 146-168.

Sahaj, Tomasz. 2012. Kibice piłkarscy jako aktorzy współczesnych widowisk sportowych (i pozasportowych), w: J. Ciechowicz, W. Moska (red.), Futbol w świecie sztuki, Gdańsk: UG, s. 35-49.

Schechner, Richard. 2006. Performatyka. Wstęp, Wrocław: Instytut im. Jerzego Grotowskiego.

Smart, Barry. 2007. Not playing around: global capitalism, modern sport and consumer culture, „Global Networks” 7: 113-134. 
Wachowski, Jacek. 2011. Performans, Gdańsk: słowo/obraz terytoria.

Wąsowicz, Jarosław. 2006. Biało-zielona „, Solidarność”. O fenomenie politycznym kibiców gdańskiej Lechii 1981-1989. Gdańsk: Finna.

Zieliński, Roman. 1993. Pamiętnik kibica. Ludzie z piętnem Heysel, Wrocław: [b.w.].

Zieliński, Roman. 1997. Liga chuliganów, Wrocław: Croma.

\section{THE PERFORMANCE ON THE TERRACES.}

\section{ABOUT A CULTURALLY-DRAMATURGICAL ASPECT OF FANDOM}

The main purpose of the article is to show that in a certain dimension, the activity of football supporters constitutes a kind of performance. The attention is focused on "hardcore" football fans (called "ultras", responsible for preparing choreographies at matches) in Poland. Performances prepared by fans are not only aesthetic representations, but they represent a particular, cultural content. Presenting technical skills (preparation of match choreography, painting, etc.) intertwines with a cultural background. In the case of football fandom different dimensions - oppositions, chronologies and analogies - comprise culture of the fans. A broadly understood tradition (the history of the club, and the history of the region or of Poland generally) plays a very important role in the fans' performances. Analyses of performances are placed in the broader context of the changes in modern football, most of all the process of commercialization. The role of the traditional fans is undermined by the meaning of a new group of "consumer-fans", and for the traditional ones the creation of performances is becoming one of the last bastions of presenting the content of their own culture and common identity.

Key words: fandom culture, theory of performance, modern football, choreographies, the frame of interpretation 